\title{
Fatal Human herpesvirus 1 (HHV-1) infection in captive marmosets (Callithrix jacchus and Callithrix penicillata) in Brazil: clinical and pathological characterization ${ }^{1}$
}

\author{
Renata A. Casagrande ${ }^{2}$, Cláudio S. Pannuti ${ }^{3}$, Cristina Kanamura ${ }^{4}$, Wilton S. Freire ${ }^{3}$, \\ André Grespan ${ }^{5}$ and Eliana R. Matushima ${ }^{2 *}$
}

\begin{abstract}
Casagrande R.A., Pannuti C.S., Kanamura C., Freire W.S., Grespan A. \& Matushima E.R. 2014. Fatal Human herpesvirus 1 (HHV-1) infection in captive marmosets (Callithrix jacchus and Callithrix penicillata) in Brazil: clinical and pathological characterization. Pesquisa Veterinária Brasileira 34(11):1109-1114. Departamento de Patologia, Faculdade de Medicina Veterinária e Zootecnia, Universidade de São Paulo, Av. Orlando Marques de Paiva 87, São Paulo, SP 05508-900, Brazil. E-mail: ermatush@usp.br

Fatal Human herpesvirus 1 (HHV-1) was diagnosed in 12 captive marmosets (Callithrix jacchus and Callithrix penicillata) from metropolitan region of São Paulo, São Paulo State. Clinical signs were variable among the cases, but most affected marmosets presented signs associated with viral epithelial replication: oral, lingual and facial skin ulcers and hypersalivation, and viral replication in the central nervous system: prostration, seizure and aggressive behavior. Consistent microscopic findings were diffuse mild to severe nonsuppurative necrotizing meningoencephalitis with gliosis, vasculitis and neuronal necrosis. Additionally, in the brain, oral cavity, skin, adrenal gland and myoenteric plexus intranuclear inclusion bodies were present. Immunohistochemistry confirmed the presence of the HHV-1 antigen in association with lesions in the brain, oral and lingual mucosa, facial skin, adrenal gland and myoenteric plexus. HHV-1-specific polymerase chain reaction (PCR) analysis of the brain was carried out and the virus was detected in $7 / 8$ infected marmosets. It is concluded that HHV-1 causes widespread fatal infection in marmosets.
\end{abstract}

INDEX TERMS: Human herpesvirus 1, marmosets, Callithrix jacchus, Callithrix penicillata, herpetic infection, viral encephalitis, nonhuman primate pathology, clinical signs, immunohistochemistry, PCR.

RESUMO.- [Infecção fatal por Herpesvirus simplex Tipo 1 (HHV-1) em saguis de cativeiro (Callithrix jacchus and Callithrix penicillata) no Brasil: caracterização clínica e patológica.] Infecção fatal por Herpesvirus simplex Tipo 1 (HHV-1) foi diagnosticada em 12 saguis de cativeiro (Callithrix jacchus e Callithrix penicillata) provenientes da região

\footnotetext{
${ }^{1}$ Received on February 4, 2014.

Accepted for publication on October 10, 2014.

${ }^{2}$ Departamento de Patologia, Faculdade de Medicina Veterinária e Zootecnia (FMVZ, Universidade de São Paulo (USP), Av. Prof. Dr. Orlando Marques de Paiva 87, Cidade Universitária, São Paulo, SP 05508-900, Brazil. *Corresponding author: ermatush@usp.br

${ }^{3}$ Laboratório de Virologia, Instituto de Medicina Tropical de São Paulo (IMTSP), USP, Av. Dr. Enéas de Carvalho Aguiar 470, Jardim América, São Paulo, SP 05403-000.

${ }^{4}$ Instituto Adolfo Lutz, Av. Dr. Arnaldo 355, Cerqueira César, São Paulo, SP 01246-000.

${ }^{5}$ Clínica Veterinária Wildvet, Rua Professor Vahia de Abreu 514, Itaim Bibi, São Paulo, SP 04549-002.
}

metropolitana de São Paulo, Estado de São Paulo. Os sinais clínicos foram variáveis entres os casos, no entanto, a maioria dos saguis afetados apresentavam sinais associados à replicação viral em epitélios: úlceras na cavidade oral, língua e pele da face e hipersalivação; e no sistema nervoso central: prostração, convulsão e comportamento agressivo. Histologicamente, o principal achado foi meningoencefalite necrosante não supurativa difusa, leve a acentuada com gliose, vasculite e necrose neuronal. Inclusões intranucleares também foram observadas em encéfalo, cavidade oral, pele, glândula adrenal e plexo mioentérico. A imuno-histoquímica anti-HHV-1 confirmou a presença do antígeno viral em associação às lesões em encéfalo, mucosa oral e lingual, pele da face, glândula adrenal e plexo mioentérico. Em 7/8 saguis infectados foi detectada a presença de HHV-1 por reação em cadeia da polimerase (PCR) a partir de amostras de encéfalo. Conclui-se que HHV-1 causa uma infecção disseminada e fatal em saguis. 
TERMOS DE INDEXAÇÃO: Herpesvirus simplex Tipo 1, saguis, Callithrix jacchus, Callithrix penicillata, infecção herpética, encefalite viral, patologia de primata não-humano, sinais clínicos, imuno-histoquímica, PCR.

\section{INTRODUCTION}

Human herpesvirus 1 (HHV-1), commonly referred as Herpes simplex virus type 1 , is a well-known human-to-nonhuman primate transmissible virus. Humans are the original host and reservoir with either typical symptoms of acute gingivostomatitis or asymptomatic infection (Roizman et al. 2007). HHV-1 is spread by direct contact with infected secretions, usually from orolabial vesicles ('cold sores') (Kolokotronis \& Doumas 2006). After local replication, the virus is conveyed by retrograde axonal transport along sensory fibers to the trigeminal ganglion, where, after further replication, latent infection is established (Roizman et al. 2007).

Although reactivation of the viral infection may occur spontaneously, predisposing factors include local mucocutaneous trauma, ultraviolet irradiation or systemic factors such as emotional and physical stress, pyrexia and immunosuppression. The possible outcomes of viral reactivation are: asymptomatic stage, development of cold sores or viral encephalitis (Kolokotronis \& Doumas 2006, Roizman et al. 2007).

Infection by HHV-1 in nonhuman primates is sporadic and occurs through close contact with humans. In Old World primates, natural infection has been described in gibbons (Hylobates lar) (Smith et al. 1969), gorillas (Gorilla gorilla) (Marennikova et al. 1973), and chimpanzees (Pan troglodytes) (McClure et al. 1980). Usually, in these species the disease is confined to vesicles and ulcers in the skin and mucous membranes.

New World primates appear to be more susceptible to HHV-1. Infection has been described in owl monkeys (Aotus trivirgatus and A. nancymae) (Melendez et al. 1969, Gozalo et al. 2008), white-faced Saki (Pithecia pithecia) (Schrenzel et al. 2003) and marmosets (Callithrix sp.) (Murphy et al. 1972, Juan-Sallés et al. 1997, Huemer et al. 2002, Matz-Rensing et al. 2003, Hatt et al. 2004, Lefaux et al. 2004), resulting in lethal infection.

In Brazil, few cases of HHV-1 infection in marmosets have been reported (Bruno et al. 1997, Costa et al. 2011, Longa et al. 2011). In this paper, we describe the clinical signs and gross and histopathological lesions of twelve captive marmosets (Callithrix jacchus and C. penicillata) spontaneously infected by HHV-1. The objective of this study was to enhance our understanding of HHV-1 as the causative agent of fatal meningoencephalitis and vesiculoulcerative lesions in marmosets.

\section{MATERIALS AND METHODS}

Twelve marmosets (Callithrix sp.) from metropolitan region of São Paulo, São Paulo State which had died in captivity were submitted to postmortem examination. Selected tissue samples were collected from the brain, facial skin, mouth, tongue, trachea, lungs, thyroid and adrenal glands, heart, liver, spleen, lymph nodes, esophagus, stomach, pancreas, small and large intestines, kidneys, urinary bladder, testicles or ovaries and uterus, fixed in 10\% neutral buffered formalin and embedded in paraffin. Sections of $3 \mu \mathrm{m}$, stained with hematoxylin and eosin (HE), were examined.

For the immunohistochemical analysis (IHC), the polyclonal rabbit anti-Herpes simplex virus type 1 (HHV-1) antibody ${ }^{\mathrm{a}}$ was used. The slides were deparaffinized, rehydrated, treated with $6 \%$ hydrogen peroxide in water solution and the antigens were not retrieved according to previous standardization. Sections were incubated overnight at $4^{\circ} \mathrm{C}$ with primary antibody $(1: 40,000 \mathrm{di}$ lution). Amplification of the signal was achieved using biotinylated secondary antibody followed by labeled streptavidin-biotin-peroxidase complex ${ }^{\mathrm{b}}$. The chromogen used for the developing was diaminobenzidine ${ }^{c}$. Slides were counterstained with Harry's hematoxylin and coverslipped for microscopic examination. A positive control (human brain tissue positive for HHV-1) was also included in this procedure. The tissue samples were categorized as negative $(-)$, discrete reaction intensity $(+)$, moderate $(++)$, and accentuated (+++).

Direct typing of Herpes simplex virus (HSV) by the polymerase chain reaction (PCR) technique was performed (Nascimento et al. 1998). One common upstream primer and two type-specific downstream primers were prepared to amplify DNA from the HSV type 1 and type 2 DNA polymerase genes. Three primers were selected for two assays. The first, designated HSV-U (5'- GAGCCACTTCCAGAAGCGCAG-3'), serves as the upstream primer for both assays. The oligonucleotides used as downstream primers were 5'-GTTCGTCCTCGTCCTCCCC-3', (designated HSV-1L) for HHV-1 and 5'-GGGGCCTCCTTGTCGAG-3' (designated HSV-2L) for HHV-2. The products of standard HHV1 and HHV-2 strains had predicted sizes of 503 and 435 base pairs, respectively, and the difference in molecular mass enabled us to type the HSV strain.

DNA extraction was performed with Tissue Kit ${ }^{\mathrm{d}}$ on fragments of brain $(8 / 12)$ and tongue (2/12) obtained from the marmosets. The amplification was performed in a thermocyclere with 35 cycles run at $94^{\circ} \mathrm{C}(1 \mathrm{~min}), 65^{\circ} \mathrm{C}(1 \mathrm{~min})$ and $72^{\circ} \mathrm{C}(1 \mathrm{~min})$, followed by a final run at $72^{\circ} \mathrm{C}(10 \mathrm{~min})$. Amplified DNA was electrophoresed on $2 \%$ agarose gel containing $0.5 \mu \mathrm{g}$ of ethidium bromide per $\mathrm{ml}$ and examined under UV light.

\section{RESULTS \\ Animal history and clinical findings}

Herpetic infection was diagnosed in six white-tufted-ear marmosets (Callithrix jacchus), five black-tufted-ear marmosets (C. penicillata) and one hybrid (C. jacchus x $C$. penicillata), comprising nine adult and three young animals. All marmosets were pet animals, and had had close contact with humans. Two of the marmoset owners (case 2 and cases 8-11) had frequent episodes of oral herpetic infection; however, in the latter case the owner avoided direct contact with the marmosets during the clinical stage of the disease. The owners had had herpes labialis a few days prior to the development of the clinical signs in the marmosets. The owner of the marmosets denoted as cases 3 and 4 used to feed the marmosets by placing the food in her mouth to be taken by the animals. In the remaining cases, there was no evidence of close contact with people presenting herpetic lesions.

A summary of the duration and frequency of clinical signs is presented in Table 1. The clinical course of the disease was acute, varying from 1 to 4 days (average of 3 days). Two marmosets (cases 10 and 11) were treated with Aciclovir and survived for 16 and 23 days, respectively. Seven 
marmosets showed signs of neurological disturbance and herpetic lesions in the mucous membranes and skin. Two animals showed signs of neurological disturbance without herpetic lesions, two were found dead and one had signs of gastroenteric problems, such as diarrhea. Apart from prostration and appetite loss (10/12), the clinical signs of the cases were varied, but most of affected marmosets presented signs associated with neurological lesions $(9 / 12)$ and viral replication in mucosae/skin (ulcers) $(7 / 12)$. There was no history of intercurrent illness, stress or immunosuppression in these marmosets.

Three of the marmosets were treated with $50 \mathrm{mg} / \mathrm{kg}$ of Aciclovir associated with $1 \mathrm{mg} / \mathrm{kg}$ of levamisole phosphate in oral suspension twice daily for 3 days (case 9) and 7 days (cases 10 and 11). Additionally, marmosets 10 and 11 received $10 \mathrm{mg} / \mathrm{kg}$ of Valacyclovir twice in oral suspension for a further 7 days. In case 2, the owner administered 500 mg of Sodic Dipyrone and 500 mg of Cefalexin in oral suspension once daily for 2 days. The marmoset of case 3 was treated with a single intra-muscular dose of $0.1 \mathrm{mg} / \mathrm{kg}$ of Diazepam and $4 \mathrm{ml}$ of glucose $5 \%$ solution subcutaneously. The animal of case 5 received $25 \mathrm{mg} / \mathrm{kg}$ of Sulfamethoxazole and Trimethoprim and $5 \mathrm{ml}$ of Ringer's lactate solution subcutaneously once daily for 2 days; in case 12 the marmoset was given $5 \mathrm{mg} / \mathrm{kg}$ Enrofloxacin intramuscularly and $5 \mathrm{ml}$ of Ringer's lactate solution subcutaneously once

Table 1. The main clinical signs of the marmosets naturally infected by Human herpesvirus 1 (HHV-1)

\begin{tabular}{llllllllllllll}
\hline Cases & & 1 & 2 & 3 & 4 & 5 & 6 & 7 & 8 & 9 & 10 & 11 & 12 \\
\hline Clinical & Evolution (days) & $*$ & 3 & 3 & 2 & 2 & 3 & 1 & $*$ & 3 & 16 & 23 & 4 \\
signs & Aggressive behavior & - & + & - & - & - & - & + & - & - & - & - & - \\
& Seizures & - & + & + & + & - & + & + & - & + & + & + & + \\
& Hypersalivation & - & + & - & + & - & - & - & - & - & - & - & - \\
& Hypothermia & - & - & + & - & + & - & - & - & - & - & - & - \\
& Nystagmus or anisocoria & - & - & - & - & - & - & - & - & - & - & + & + \\
& Paresis & - & - & + & - & - & - & - & - & - & - & - & - \\
& Prostration and appetite loss & - & + & + & + & + & + & + & - & + & + & + & + \\
& Ulcers of skin of face, oral & - & + & + & + & - & + & - & - & + & + & + & - \\
& mucous and tongue & & & & & & & & & & & & \\
& Vomiting or diarrhea & - & - & - & + & - & - & - & - & -
\end{tabular}

* Found dead; + clinical sign present; - clinical sign absent. daily for 2 days. The animals of cases 1, 4, 6, 7 and 8 did not receive any treatment.

\section{Gross and histopathological lesions}

Multiple ulcers were seen throughout the facial skin of the marmosets (7/12) (Fig.1A). The ulcers on the face were usually accompanied by locally extensive fibrinonecrotic glossitis and stomatitis (Fig.1B). Gross findings in the brain included mild to severe congestion of the leptomeninges $(7 / 12)$ and edema characterized by swollen brain and flattening of the gyri. In one marmoset (case 10) there was a focal area of hemorrhage in the cerebellum. Lungs were red, heavy and wet $(5 / 12)$. The liver was yellowish, mildly to severely enlarged with accentuation of the lobular pattern $(7 / 12)$. Additional macroscopic findings included splenic congestion $(6 / 12)$, widespread enlargement of the lymph nodes (2/12) and pale kidneys with multiple, $1 \mathrm{~mm}$, white foci throughout the cut surface $(1 / 12)$.

The most prominent microscopic findings were nonsuppurative meningoencephalitis with necrotizing vasculitis (Fig.2A). Lesions were characterized by inflammatory infiltrate composed of lymphocytes, macrophages and plasma cells in the Virchow-Robin spaces, extending into the leptomeninges. Variable degrees of acute neuronal necrosis (mainly in the cerebral cortex and hippocampus) and neuronophagia admixed with aggregates of neutrophils were observed throughout the gray matter. Malacia was noted in the cerebral cortex and was characterized by necrosis of the neuroectodermal elements with maintenance of mesenchymal structures (vessels and microglia). Multifocally, there was fibrinoid degeneration of the wall of the medium-sized vessels with occasional neutrophilic vasculitis. Necrosis of Purkinje cells in the cerebellum was associated with necrotizing vasculitis in the granular cell layer (case 3).

Intranuclear basophilic inclusion bodies were observed in neurons of the cerebral and cerebellar cortex and hippocampus (7/12) (Fig.2B). Similar herpetic inclusion bodies were seen in the epithelium of the tongue (4/12), mouth (4/12) and facial skin (2/12) and in the cortical cells of the adrenal glands $(2 / 12)$. The inclusion bodies

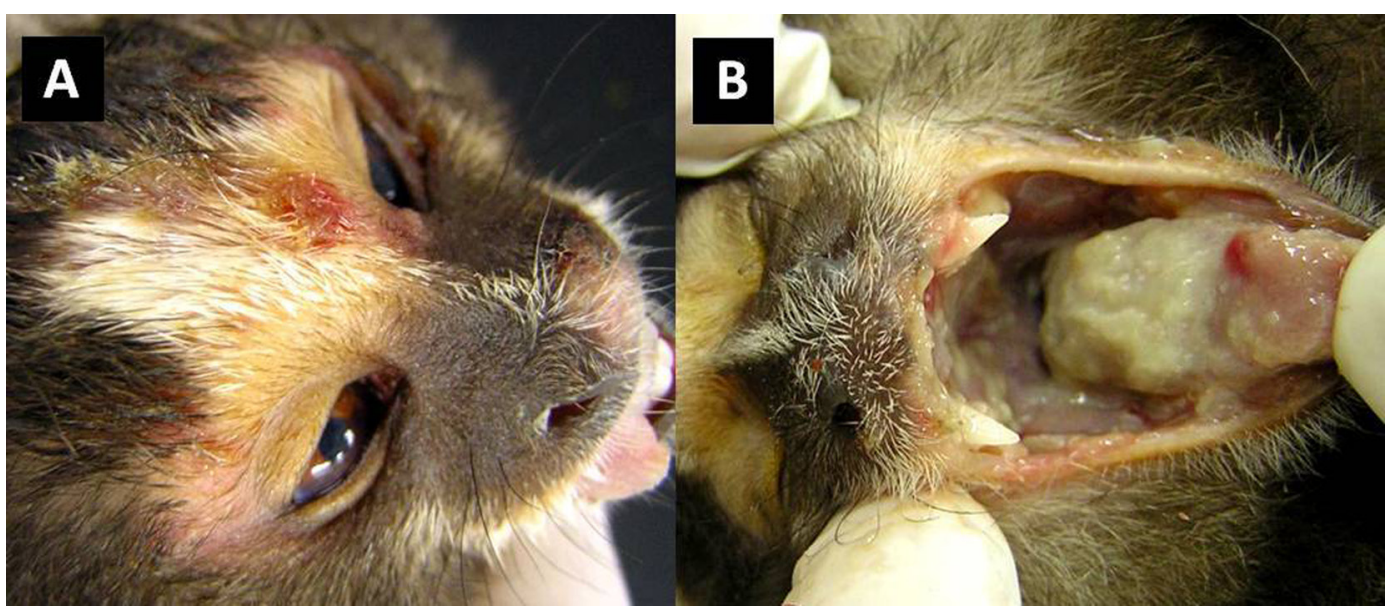

Fig.1. Fatal Human herpesvirus 1 (HHV-1) infection in marmosets. (A) The face has an ulcer covered with crusts. (B) Epithelium of the oral cavity and tongue is focally extensively ulcerated and covered with grey-whitish fibrinous plaques. 


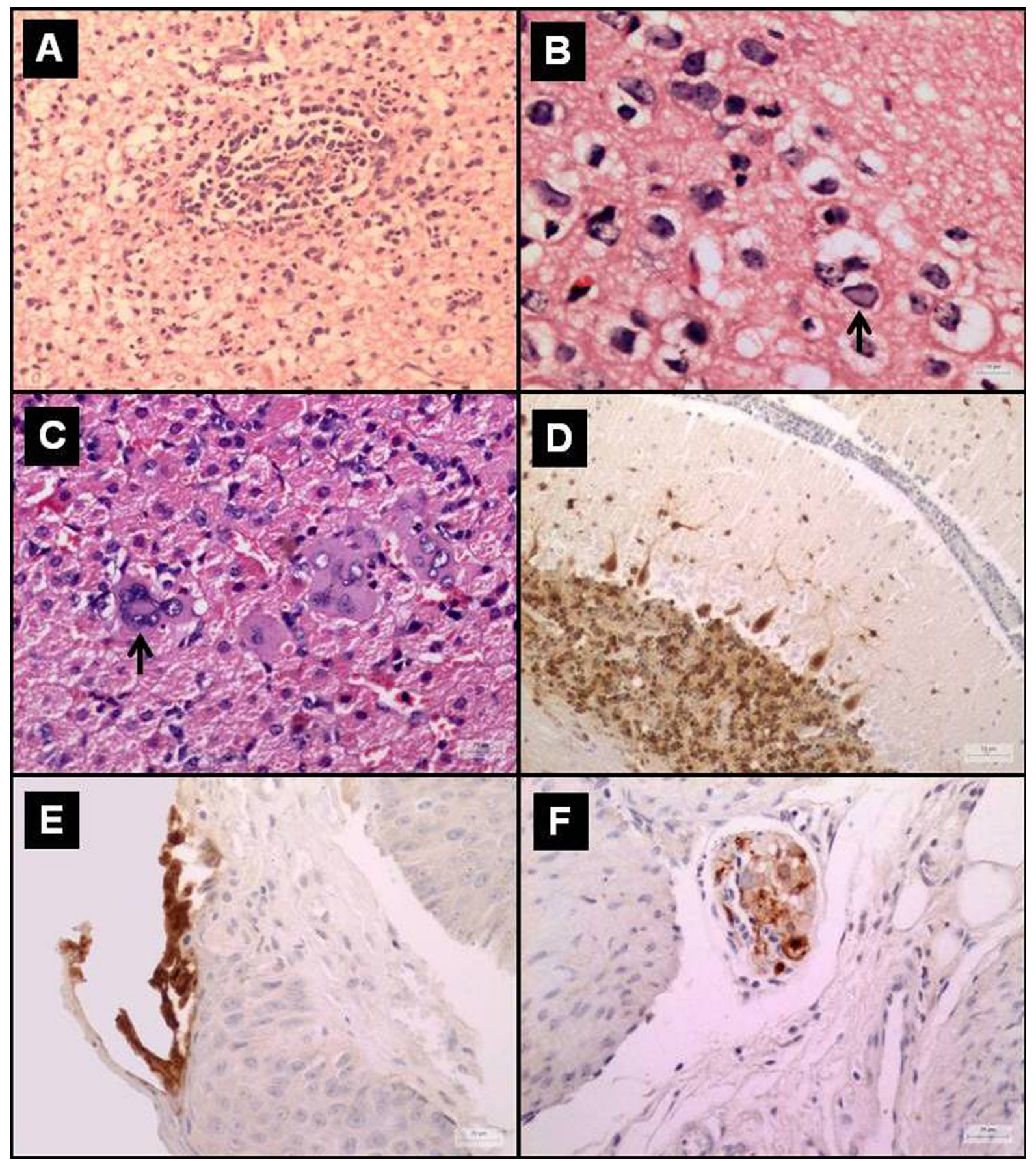

Fig.2. Fatal Human herpesvirus 1 (HHV-1) infection in marmosets. (A) Cerebral cortex with necrotizing vasculitis associated with small aggregates and diffuse infiltration of lymphocytes, macrophages, glial cells, and some neutrophils and neuropil necrosis. HE, Bar $=50 \mu \mathrm{m}$. (B) Intranuclear basophilic inclusion body observed in the neurons (arrow). HE, Bar=10 $\mu$ m. (C) Syncytial cells present in the adrenal cortex. HE, Bar=25 $\mu \mathrm{m}$. (D) Cerebellum, specific staining for HSV1 antigen in cytoplasm and nucleus Purkinje neurons and in the neurons of the granular cell layer. HSV1 immunohistochemistry, Bar $=50 \mu \mathrm{m}$. (E) Tongue, specific labeling for viral antigen in the nucleus and cytoplasm of epithelium adjacent to the area of necrosis. HSV1 immunohistochemistry, Bar=25 $\mu$ m. (F) Auerbach's plexus, specific labeling of viral antigen within the cytoplasm and nucleus of neurons. HSV1 immunohistochemistry. Bar=25 $\mu$ m.

were closely associated with random foci of epidermal or epithelial ulceration and adrenal necrosis along with mild to severe lymphoplasmacytic inflammatory infiltrate. Lymphoplasmacytic ganglionitis of the myoenteric plexus with neuronal necrosis and occasional intranuclear eosinophilic inclusion bodies were also observed (2/12).

Mild to severe lymphoplasmacytic inflammatory infil- trate was also seen throughout other organs including the trachea, lungs, thyroid gland, heart, stomach, intestines, and pancreas. Multinucleated syncytial cells were found in the spleen, lymph nodes, liver, kidneys and adrenal glands (2/12) (Fig.2C). Additional microscopic findings in the liver were related to hepatic lipidosis and characterized by vacuolation of the hepatocyte cytoplasm. The ulcers on the 
Table 2. Immunohistochemistry and PCR evaluation anti-Human herpesvirus 1 (HHV-1) in marmosets

\begin{tabular}{|c|c|c|c|c|c|c|c|c|c|c|c|c|}
\hline Cases & 1 & 2 & 3 & 4 & 5 & 6 & 7 & 8 & 9 & 10 & 111 & 12 \\
\hline Adrenal gland & + & - & - & +++ & - & - & - & - & ++ & ++ & - & - \\
\hline Cerel & - & - & ++ & ++ & - & - & - & - & ++ & - & - & - \\
\hline Cerebrum & + & ++ & +++ & ++ & + & + & + & + & ++ & ++ & +++ & ++ \\
\hline Mouth & - & - & ++ & ++ & - & + & - & ++ & ++ & - & - & - \\
\hline Myoenteric plexus & - & - & + & + & + & - & - & - & + & - & - & - \\
\hline Ovary & - & - & - & - & - & - & - & - & - & + & - & - \\
\hline Skin & - & - & + & - & - & + & - & - & - & - & - & - \\
\hline Testicle & - & - & + & - & - & - & - & - & - & - & - & - \\
\hline Tongue & - & - & ++ & ++ & - & + & - & ++ & ++ & - & - & - \\
\hline PCR for HHV-1 & np & $\mathrm{np}$ & + & + & np & + & - & + & + & & & np \\
\hline
\end{tabular}

skin and oral cavity were covered with cell debris, fibrin and multiple colonies of bacteria. At the margins of the ulcers there was severe intracellular edema with occasional formation of intraepidermal vesicles.

\section{Immunohistochemistry}

In the IHC analysis carried out with polyclonal antibodies against HSV1 the most intense signal scores were obtained for the cerebrum and cerebellum. The IHC results are reported in Table 2. Immunostaining for HSV1 could be detected in the nucleus and cytoplasm of neurons and glial cells of the cerebral cortex and hippocampus of all animals with additional signaling in the Purkinje neurons and granular cell neurons of the cerebellum (3/12) (Fig.2D). In the facial skin, tongue and oral mucosa virus-positive cells were found in the nucleus and cytoplasm of epithelium adjacent to the area of necrosis (5/12) (Fig.2E). Positive reaction was also observed in neurons in the myoenteric plexus (4/12) (Fig.2F) and urinary bladder ganglion (1/12), in the medullar and cortical of adrenal glands (4/12), in salivary gland ducts in the tongue $(1 / 12)$, in seminiferous tubule cells $(1 / 12)$ and in follicular cells of the ovary $(1 / 12)$.

\section{PCR}

Brain samples from seven marmosets (cases 3, 4, 6, 8, 9, 10 and 11) and tongue samples from two animals (cases 3 and 4) tested positive for HHV-1. In the case of four marmosets the PCR was not performed (cases 1, 2, 5 and 12) and in one case (case 7) it was negative.

\section{DISCUSSION}

Based on the epidemiology of the cases in this study, it was verified that Neotropical primates are highly susceptible to HHV-1 (Melendez et al. 1969, Murphy et al. 1972, Bruno et al. 1997, Juan-Sallés et al. 1997, Huemer et al. 2002, Matz-Rensing et al. 2003, Schrenzel et al. 2003, Hatt et al. 2004, Lefaux et al. 2004, Gozalo et al. 2008, Costa et al. 2011, Longa et al. 2011). This virus causes an acute and fatal disease in marmosets, characterized by multiple skin vesicles and ulcers as well as severe necrotizing meningoencephalitis (Juan-Sallés et al. 1997, Hatt et al. 2004, Lefaux et al. 2004, Longa et al. 2011).

The clinical course of the disease varies from sudden death (Matz-Rensing et al. 2003, Hatt et al. 2004) to acute death, with an average evolution of 3 days (1-4 days) (Juan-Sallés et al. 1997, Matz-Rensing et al. 2003, Hatt et al. 2004, Lefaux et al. 2004); however, when the animals received treatment with Aciclovir, an antiviral drug, some animals survived for up to 2-3 weeks (Hatt et al. 2004, Lefaux et al. 2004).

The association of ulcerative lesions in the skin/mucosae with neurological signs in marmosets is highly suggestive of herpetic disease which can be caused by HHV-1, HHV-2 or Saimiriine herpesvirus 1 (Herpes T) (Melnick et al. 1964, Holmes et al. 1966). The only recognized natural host for Herpes $\mathrm{T}$ is the squirrel monkeys (Saimiri sciureus) (King et al. 1967). Thus, Herpes $T$ can be ruled out as the agent promoting herpesviral infections in these marmosets because there is no evidence of contact with squirrel monkeys. However, a definitive diagnosis can only be made by immunostaining techniques and molecular investigations, as described in this study. In this study, all HHV-1 infections were confirmed by IHC and 7/8 cases also by PCR.

Similarly, HHV-1 and HHV-2 can cause the same lesions in other New World primate species, such as the owl monkey (Gozalo et al. 2008, Melendez et al. 1969) and the white-faced Saki (Schrenzel et al. 2003). In humans and Old World primates these viruses commonly produce herpetic lesion with neurological signs in immunosuppressed (Smith et al. 1969, Whitley \& Kimberlin 2005) or young subjects (Heldstab et al. 1981, Whitley \& Kimberlin 2005).

When ulcerative lesions on the skin are absent or there is a lack of inclusion bodies in the neurons (Juan-Sallés et al. 1997), the diagnosis of herpetic infection can be challenging and other agents which can cause encephalitis, such as rabies, should be included in the differential diagnoses (Favoretto et al. 2001).

Although many cases of HHV-1 in marmosets demonstrate little systemic involvement, (Juan-Sallés et al. 1997, Matz-Rensing et al. 2003, Hatt et al. 2004, Lefaux et al. 2004), this study verified widespread viral antigen throughout many organs using immunohistochemistry. In this study was observed that anti-HHV-1 immunostaining was more frequent in the brain $(12 / 12)$ and mucosa of oral cavity and tongue (5/12). Therefore, these organs are essential for IHC examination. The HHV-1 pathogenesis in marmosets is not well-understood. Multi-organ disease can be the consequence of viremia in a host not capable of limiting replication on mucosal surfaces (Whitley \& Kimberlin 2005).

The source of infection was most likely due to close interaction between humans and marmosets. In the present study, some owners had labial herpetic infection while others did not. Having marmosets as pet animals or feeding these animals in zoos through close contact is a very common practice and usually the most common source of infection (Juan-Sallés et al. 1997, Matz-Rensing et al. 2003, Lefaux et al. 2004). Although not recorded in this study, close interaction between humans and marmosets can represent a threat for humans, since marmosets can be a source infections such as rabies (Favoretto et al. 2001).

Moreover, in the case of close contact between marmo- 
sets a high transmissibility of HHV-1 has been revealed, since all marmosets of the same group developed the disease. The rapid dissemination within the group suggests that the transmission occurs from marmoset to marmoset (Matz-Rensing et al. 2003, Hatt et al. 2004, Lefaux et al. 2004).

PCR techniques are useful for the rapid diagnosis of HHV-1 in marmosets (Juan-Sallés et al. 1997, Huemer et al. 2002, Matz-Rensing et al. 2003, Lefaux et al. 2004). If HHV-1 latency in surviving primates (Hatt et al. 2004) and animal-to-animal transmission occur then HHV-1 should be included as a health care concern in reintroduction programs for susceptible primates (Juan-Sallés et al. 1997).

The infection of marmosets by HHV-1 appears to be rare and it could thus be erroneously concluded that these animals show low risk of infection; however, evidence to the contrary was observed in this study and in many others reported in the literature (Murphy et al. 1972, Juan-Sallés et al. 1997, Huemer et al. 2002, Matz-Rensing et al. 2003, Hatt et al. 2004, Lefaux et al. 2004).

In Brazil, there are few reports of HHV-1 being proposed as the causative agent of death in marmosets with vesicles and ulcers on the skin and mucous membranes (Bruno et al. 1997, Costa et al. 2011, Longa et al. 2011). Therefore, an important result of this study is the verification of the existence of HHV-1 as the causative agent of fatal and disseminated infections in marmosets in Brazil.

Acknowledgments.- We are grateful to Pós-Graduação em Patologia Experimental e Comparada da FMVZ/USP, Dr. Raquel Rubia Rech for excellent constructive criticism in relation to this paper, and Dr. Adriana Joppert, Dr. Giordana Ysis, Dr. Marcelo Gomes and Dr. Marta Guimarães for providing the animals for this study. This work was financially supported by the Brazilian National Council of Scientific and Technologic Development (CNPq).

Sources and Manufacturers.- (a) Anti-Herpes simplex virus type 1 (HSV1) polyclonal antibody, Dako Cytomation, Glostrup, Denmark. (b) LSAB Universal kit, Dako Cytomation, Glostrup, Denmark.

(c) DAB, Sigma-Aldrich, Saint Louis, Missouri, United States. (d) DNA extraction tissue Kit, Qiagen, São Paulo, SP, Brazil. (e) Thermocycler 480, Perkin-Elmer Cetus, Norwalk, Connecticut, United States.

\section{REFERENCES}

Bruno S.F., Liebhold M.M., Matz-Rensing K., Romao M.A.P., Didier A., Brandes F., Bressan A.C.S. \& Kaup F.J. 1997. Herpesvirus infection in free-living black-tufted-ear marmoset (Callithrix penicillata E. Geoffroyi 1812) at the State Park of Serra da Tiririca, Niterói, Rio de Janeiro, Brasilien. Berl. Münch. Tierärztl. Wochenschr. 110:427-430.

Costa E.A., Luppi M.M., Malta M.C.C., Moreira A.P., Luiz F., Araujo M.R., Coelho F.M., Fonseca F.G., Ecco R. \& Resende M. 2011. Outbreak of Human Herpesvirus Type 1 infection in nonhuman primates (Callithrix penincillata). J. Wildl. Dis. 47:690-693.

Favoretto S.R., Mattos C.C., Morais N.B., Araújo F.A.A. \& Mattos C. 2001. Rabies in marmosets (Callithrix jacchus), Ceará, Brazil. Emerg. Infect. Dis. 7:1062-1065.

Gozalo A.S., Montoya E.J. \& Weller R.E. 2008. Dyscoria associated with Herpesvirus infection in Owl Monkeys (Aotus nancymae). J. Am. Assoc. Lab. Anim. Sci. 47:68-71.
Hatt J.M., Grest P., Posthaus H. \& Bossart W. 2004. Serologic survey in a colony of captive common marmosets (Callithrix jacchus) after infection with Herpes simplex type1-like virus. J. Zoo Wildl. Med. 35:387390.

Heldstab A., Rüedi D., Sonnabend W. \& Deinhardt F. 1981. Spontaneous generalized Herpesvirus hominis infection of a lowland gorilla (Gorilla gorilla gorilla). J. Med. Primatol. 10:129-35.

Holmes A.W., Devine J.A., Nowakowski E. \& Deinhardt F. 1966. The epidemiology of a herpes virus infection of New World monkey. J. Immunol. 96:668-671.

Huemer H.O., Larcher C., Czedik-Eysenberg T., Nowotny N. \& Reifinger M. 2002. Fatal infection of a pet monkey with Human herpesvírus 1. Emerg. Infect. Dis. 8:639-641.

Juan-Sallés C., Ramos-Vara J.A., Prats N., Solé-Nocolás J., Segalés J. \& Marco A.J. 1997. Spontaneous Herpes simples virus infection in common marmosets (Callithrix jacchus). J. Vet. Diagn. Invest. 9:341-345.

King N.W., Hunt R.D., Daniel M.D. \& Melendez L.V. 1967. Overt herpes-T infection in squirrel monkeys (Saimiri sciureus). Lab. Anim. Care 17:413423.

Kolokotronis A. \& Doumas S. 2006. Herpes simplex virus infection, with particular reference to the progression and complications of primary herpetic gingivostomatitis. Clin. Microbiol. Infect. 12:202-211.

Lefaux B., Duprez R., Tanguy M., Longeart L., Gessain A. \& Boulanger E. 2004. Letter to the editor. Vet. Pathol. 41:302-303.

Longa C.S., Bruno S.F., Pires A.R., Romijn P.C., Kimura L.S. \& Costa C.H.C. 2011. Human Herpesvirus 1 in Wild Marmosets, Brazil, 2008. Letter to the editor. Emerg. Infect. Dis. 17:1308-1310.

Marennikova S.S., Maltseva V.I., Shelukhina E.M., Shenkman L.S. \& Korneeva V.I. 1973. A generalized herpetic infection simulating smallpox in a gorilla. Intervirology 2:280-286.

Matz-Rensing K., Jentsch K.D., Rensing S., Langenhuyzen S., Verschoor E., Niphuis H. \& Kaup F.J. 2003. Fatal Herpes simplex infection in a group of common marmosets (Callithrix jacchus). Vet. Pathol. 40:405-411.

McClure H.M., Swenson R.B., Kalter S.S. \& Lester T.L. 1980. Natural genital Herpesvirus hominis infection in chimpanzees. Lab. Anim. Sci. 30:895901.

Melendez L.V., Espana C., Hunt R.D. \& Daniel M.D. 1969. Natural Herpes simplex infection in the owl monkey (Aotus trivirgatus). Lab. Anim. Care 19:38-45.

Melnick J.L., Midulla M., Wimberly I., Barrera-Oro J.G. \& Levy B.M. 1964. A new member of the herpesvirus group isolated from South American marmosets. J. Immunol. 92:596-601.

Murphy B.L., Maynard J.E., Krushak D.H. \& Berquist K.R. 1972. Microbial flora of imported marmosets: viruses and enteric bacteria. Lab. Anim. Sci. 22:339-343.

Nascimento M.C., Sumita L.M., Souza V.A.U.F. \& Pannuti C.S. 1998. Detection and direct typing of Herpes simplex virus in perianal ulcers of patients with AIDS by PCR. J. Clin. Microbiol. 36:848-849.

Roizman B., Knipe D.M. \& Whitley R.J. 2007. Herpes simplex Viruses, p.2501-2601. In: Knipe D.M. \& Howley P.M. (Eds), Fields virology. $5^{\text {th }}$ ed. Lippincott Williams and Wilkins, Philadelphia.

Schrenzel M.D., Osborn K.G. \& Shima A. 2003. Naturally occurring fatal herpes simplex virus 1 infection in a family of white-faced saki monkeys (Pithecia pithecia pithecia). J. Med. Primatol. 32:7-14.

Smith P.C., Yuill T.M., Buchanan R.D., Stanton J.S. \& Chaicumpa V. 1969. The gibbon (Hylobates lar): A new primate host for Herpesvirus hominis I-A natural epizootic in a laboratory colony. J. Infect. Dis. 120:292-297.

Whitley R.J. \& Kimberlin D.W. 2005. Herpes simplex: encephalitis children and adolescents. Semin. Pediatr. Infect. Dis. 16:17-23. 